Vol. 5, No. 2, 2018

https://doi.org/10.23939/eem2018.02.019

UDC 657.42

T. Shepel

$\mathrm{PhD}$ in Economics, Associate Professor

Lviv Polytechnic National University

\author{
J. Narkiewicz \\ $\mathrm{PhD}$, Associate Professor \\ Maria Curie-Skłodowska University (Poland)
}

\title{
ECONOMIC AND METHODICAL BASIS OF BIOLOGICAL ASSETS MEASUREMENT UNDER CONDITONS OF ACCOUNTING TRANSFORMATION TOWARDS IFRS
}

\begin{abstract}
Under current conditions of economic management, application of IFRS, especially IFRS 41 "Agricultural sector", is one of primary elements of ensuring successful and long-term performance for domestic agricultural enterprises as well as their mutual understanding with foreign contracting parties. Current methods of assessing biological assets and agricultural goods based on fair value of biological assets require follow-up revision, making certain adjustments to the measurement model that, in turn, will guarantee exchange equivalence between independent parties on active market.

Fundamental changes being introduced into current practice of agricultural activity accounting by Accounting Statement (Standard) 30 include allocation of plants and animals that belong to agricultural activity objects into a separate accounting category ("biological assets"), measurement of biological assets and agricultural goods based on fair value, special procedure of determining financial results.

Most often fair value of agricultural goods cannot be determined with sufficient degree of confidence. The studies have found that on account of biotransformation, measurement of biological assets based on fair value will be much different from measurement based on historic prime cost. Theoretic and methodological approaches as well as practical guidelines for biological assets and agricultural goods measurement based on fair value have been suggested, which makes it possible to measure the outcomes of agricultural activity of economic entities more objectively, extends their opportunities in terms of attracting investments and improving competitiveness on agrarian markets.
\end{abstract}

Key words: agricultural activity, IAS 41 "Agriculture", Accounting Statement (Standard) 30 "Biological assets", biotransformation, agricultural goods.

\section{Topicality of the selected subject}

In 2014 our country signed association agreement with the European Union, according to which we should implement into our legislation a range of demands aimed to improve investment climate and cooperation conditions with European partners. Among them there is increase in transparency of agricultural enterprises activity by means of legislative improvements regarding accounting, financial reporting and auditing. Introduction of amendments to the Law of Ukraine "On accounting and financial reporting" is just the first step on the way to harmonization with corresponding EU Directives and Regulations. In order to achieve the goal in view it is necessary to take more active steps in the field of accounting modernization in line with generally accepted principles and IFRS procedures. Accounting is the main informational background for management, and it should provide interested parties with true and complete information on enterprise activity. Accounting may be improved by means of adjusting it to international requirements defined within international financial reporting standards. Agriculture is considered to be one of the main investment-attractive industries in Ukraine. IFRS (IAS) 41 "Agriculture" ensures regulation of accounting process of transactions involving agricultural activity and biological assets of the institution. In this regard, practical application of regulations of IFRS 41 "Agriculture" is gaining particular significance for agricultural enterprises. It is necessary to highlight the importance of measurement principle of biological assets based on fair value, which was introduced by IFRS 41 . 


\section{Bublyk M., Didyk A.}

\section{Recent research and publications analysis}

Issues of research and development of measures for introducing IFRS into accounting practices are being studied by the following scholars: V. M. Zhuk, L. M. Kindratska, H. H. Kireitsev, O. O. Kontsurov, V. Y. Lisinf, L. I. Maksymov, V. B. Mossakovskyi and other.

Scholars choose different ways to reveal conceptual foundations and requirements concerning accounting records maintenance and preparation of financial reporting, systematizing ideas of western and domestic researchers, making references to legislative acts.

\section{Purpose and objectives of research}

The purpose of the article is to develop theoretic and methodological approaches and practical guidelines for biological assets measurement.

\section{Presentation of basic material of the research and obtained results}

IFRS (IAS) 41 establishes accounting procedure, financial reporting and disclosure of information on agricultural activity [1]. According to this standard, agricultural activity is management of biotransformation of plants and animals for the purpose of selling, receiving agricultural goods or producing additional biological assets.

Consequently, there is a need to clarify the term "biotransformation". In our opinion, these are processes of growth, degeneration, production and reproduction that cause qualitative or quantitative changes of biological asset. Biotransformation leads to changes of asset in form of its amount or quality increase or decrease. Additional assets, such as leguminous crops in plant growing and milk in animal breeding, may appear as a result of reproduction (Fig. 1).

On the basis of general conceptual framework, each agricultural enterprise may determine, within its accounting policy, clearly defined procedure of accounting management, measurement of biological assets and outcomes of their biotransformation, in accordance with the following underlying principles:

- principle of identification, which means that plants (agricultural crops) and animals used in agricultural activity are defined as biological assets in accounting system of economic entities;

- controllability concept, which means that the enterprise controls biological assets and outcomes of their biotransformation in the course of production and commercial activities;

- principle of initial and subsequent recognition - the point of initial and subsequent recognition of biological assets at fair value with the deduction of anticipated selling expenses;

- principle of value (money) measurement, which means that biological assets and agricultural goods in accounting are estimated at fair value with the deduction of anticipated selling expenses;

- principle of multiple information use, which means that accounting information on biological assets and outcomes of their biotransformation is used by the economic entity within the system of biological resources management (to prepare a special form of reporting (statement) on potential profit, expenses and financial results of agricultural activity) and in the analysis of property and financial conditions, credit worthiness etc.;

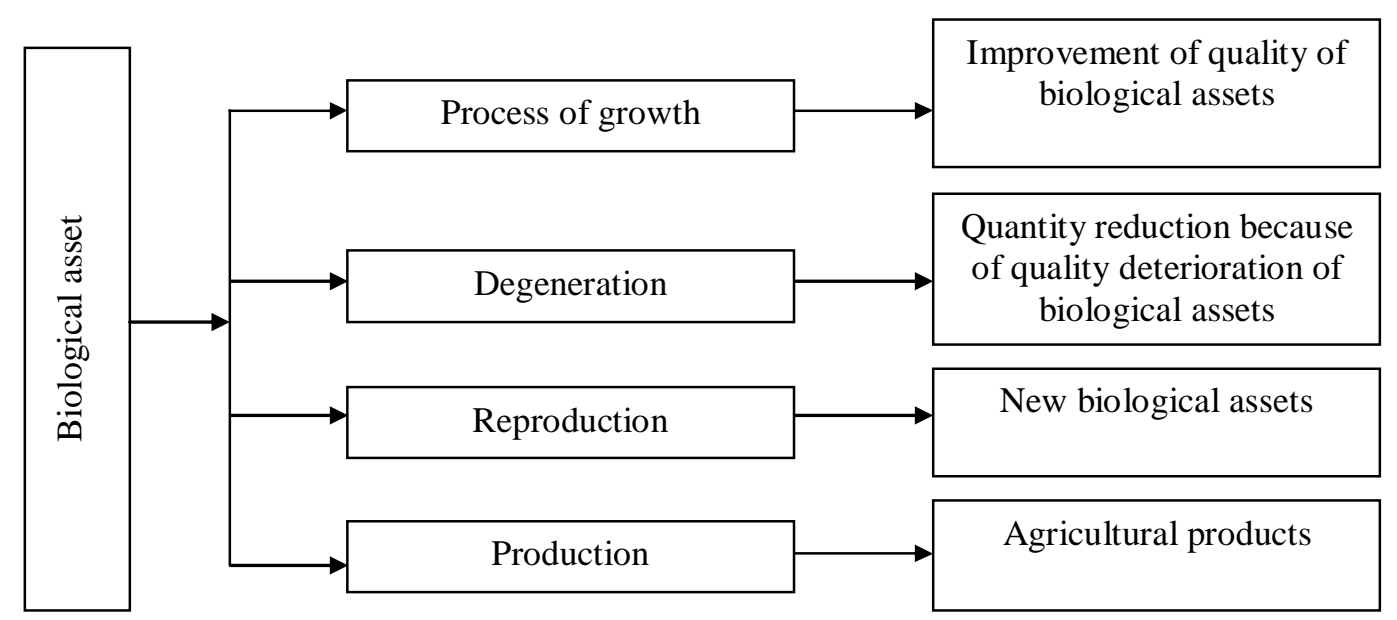

Fig. 1. Subject matter and outcome of biotransformation 
- registration principle - all transactions connected with recognition, measurement of biological assets and presentation of their biotransformation outcomes should be recorded by means of preparing relevant basic documents and registers of analytical and synthetic accounting;

- principle of tracking, measuring and presenting results of biotransformation of biological assets, which means that economic entity should periodically control and measure qualitative and quantitative changes of biological assets and outcomes of their biotransformation (profit, expenditures, financial results) and at the same time disclose them in accounting registers;

- periodicity principle, which means that fair value measurement of biological assets for the purpose of their disclosure in accounting should be carried out for every accounting date.

Measurement of changes of biological assets is the key element of biological transformation. It comprises measurement and control over the changes of quality (fat or proteins content, fiber durability, etc.) and quantity (animal yield, weight, length, etc.).

According to current IFRS (IAS) 41 requirements, all biological assets should be recognized at fair value with the deduction of selling expenses (p. 12 of IFRS (IAS) 41). This requirement is based on the fact that the best value estimation of biological assets in the course of biotransformation is their fair value. It should be noted that the standard defines the above mentioned process as the total of processes of growth, degeneration, production and procreation that lead to qualitative and quantitative changes in biological asset (p. 5 IFRS (IAS) 41).

With the introduction of Accounting Statement (Standard) 30 "Biological assets" biological assets in crop production and animal production form a component of resource potential of agricultural enterprises. Biological assets that provide economic benefit for more than 12 months are classified as long-term assets [2]. Assets that provide economic benefit during operating cycle are classified as current assets. According to p. 5253 of IFRS 41 "Agriculture", biological assets can be divided into consumable and yielding, and according to p. 54 they can be divided into mature and immature. Consumable assets are those that after achieving certain parameters can be used for their intended purpose (meat breed livestock; meat on hoof; market bird; fish in artificial lakes; forest cultivated for logging; autumn sown cereals from ripening till harvesting). Yielding assets are those that ensure production on a regular basis (dairy breeding - small and large cattle, egg laying stock, fruit trees and bushes, vineyards).

In our opinion, there is also a category of agricultural assets - derivative of biological ones. According to IFRS 41, they are classified as agricultural goods as of the time of their gathering (carcass meat, raw milk, grain, eggs, wool and other products of plant or animal origin that can not be industrially processed) [3].

It should be pointed out that material supplies of agricultural designation (account 208) are not mentioned in the international standard probably because such material supplies are also agricultural products. If they are not obtained within own household and are purchased from third parties, then IFRS 41 is not applicable to them. In such cases, IFRS 2 "Share-based payment" [4] should be followed.

The notion of biological assets and their derivatives according to Accounting Statement (Standard) 30 and Instructions № 291 [5] fully conforms the notions set out in IFRS 41, though here they are classified not so clearly as in the National Chart of Accounts.

According to information on initial recognition and measurement of biological assets, it should be noted that while Accounting Statement (Standard) 30 specifies that measurement of assets purchased from third parties should be carried out in accordance with Accounting Statement (Standard) 7 "Fixed assets", IFRS 41 does not contain explicit references that assets in such occasions should be assessed in accordance with IFRS 16 "Fixed assets".

It is necessary to note that the point of initial recognition of biological assets at fair value in accounting is the following: the date when the economic entity started measuring current biological assets at fair value; date of receipt (acquisition) of assets from third parties; date of receipt (reproduction) and start of raising/ cultivating additional biological assets directly within agricultural enterprise.

The point of further recognition of biological assets at fair value within accounting system of economic entity is the date of their revaluation as a result of biotransformation (increase, degeneration) at the beginning of every accounting period. 
Biological assets in plant growing should be recognized apart from agricultural land.

Besides, it is necessary to point out the valuation problem of non-market agricultural products that are used in production process as production stock.

We are of the opinion that their fair value (for which the market is neglected), especially as far as feeding stuff (hay, straw, herbage, etc.) of own production and by-products are concerned, should be determined on the basis of their business and economic utility. Animals are assessed at fair value with the deduction of anticipated selling expenses. Fair value of livestock is established based upon market value of animals of the same age, breed and genetic makeup.

The international financial reporting standard 41 (IAS) "Agriculture" foresees the impossibility to carry out reliable estimation of fair value: in the time of initial recognition of biological asset has no information (and can not receive it) on relevant market prices and rates, and alternative fair value measurements are not reliable. If that is the case, biological asset is measured at cost with the deduction of accumulated amortization and asset impairment loss. This regulation refers only to initial recognition of biological asset. With the advent of possibility to measure biological asset fair value with sufficient degree of reliability, the company should switch over towards measurement according to fair value with the deduction of anticipated selling expenses [6-8].

In case of acquisition of biological assets from third parties and at the moment of such acquisition their initial valuation should be carried out in accordance with IAS 16 on the ground of the fact that IAS 41 does not mention operations of biological assets acquisition from third parties. However, it is not like that.

It is clearly stated in IAS 16 that this standard is not applicable to biological assets so their initial valuation should not be carried out according to IAS 16 [9]. Consequently, this means that biological assets from the very moment of their emergence, whether it is animal yield or acquisition from third parties, should always be measured at fair value with the deduction of anticipated expenses at the place of potential sales. And only with the exception (p. 30 IAS 41) - at historical cost (id est in accordance with IAS 16) provided that this asset will be measured at fair value.
As the analysis of international financial reporting standards shows, issues of accounting items valuation are also regulated by IFRS 13 "Fair value measurement". Let us examine fundamental regulations of this standard concerning measurement of biological assets at fair value. Fair value is a price that would be received to sell an asset at measurement date in an orderly transaction between market participants, what is called the exit price [10].

The following factors should be taken into consideration in the course of fair value measurement:

1) principal market - measurement is carried out with hypothetic transaction handled on the principal market. Principal market is the market with the greatest volume of transactions for biological asset measurement. Besides, the standard specifies that principal market is the market on which the entity usually makes selling transactions of certain type of assets. In the absence of a principal market, the most advantageous market for the asset is used. In other words, this is a market that maximizes the amount that would be received to sell the asset. As of the measurement date the entity should have access to the principal or the most advantageous market;

2) asset characteristic - measurement is carried out with due account for qualitative properties and location of accounting item. This factor directly refers to biological assets since the price directly depends on physical properties. Similarly, such characteristic as location of biological asset or agricultural products has an influence on measurement. Despite the fact that within the frame of IFRS 13 costs of transactions are not included into fair value measurement, shipping costs are not classified as costs of transactions. As a consequence, fair value is corrected as expense amount incurred during asset transportation to the principal market;

3) fair value, even if the economic entity intends to use the asset in a different way;

4) measurement techniques - it is necessary to apply procedures that are viable and relevant under existing conditions and for which there is enough output information. In the course of fair value measurement it is recommended to use market-based approach. In addition to it, the standard foresees application of cost and income approaches.

Thus, measurement of biological assets should be realized from the standpoint of all market 
participants, and market environment determination should be entrusted to economic entities. This will allow taking into account differences between them since they differ in kinds of production and commercial activities.

In accordance with IFRS 13 inputs used for measurement are divided into three levels: 1) quoted prices (not adjusted) in active markets for identical assets that the entity can access at the measurement date. Active markets exist with regard to such agricultural products as grain, oil seeds, etc; 2) inputs other than quoted market prices included within Level 1 that are observable for the asset either directly or indirectly. For instance, prices disclosed in marketing researches of information agencies, State Statistics Service of Ukraine, Ministry of Agrarian Policy and Food of Ukraine; 3) relative indices of assets under review. They include rates developed by the entity itself. Thus, the cost of cattle herd bred for consumption is determined on the ground of beef price taking into account quality and finish of animals. For more efficient measurement of meat price it is meaningful to apply rates calculated on the basis of herd classification according to qualitative characteristics (for example, finish). For farm animals that will be used for further breeding, other design ratios are applied (on the basis of their external characteristic features).

Biological assets at the moment of their initial recognition and as of each accounting date should be valuated at fair value less anticipated selling costs except where fair value can not be determined with a sufficient degree of reliability (Fig. 2).

According to IFRS 41, fair value is defined as current market price less anticipated expenses at the point of future sale, except when fair value of the asset can not be measured reliably (p. 21 of IFRS 41). Expenses, anticipated at the point of sale include: commission fees for brokers and dealers; trading exchange fees; taxes and duties on sales transactions. Transportation expenses and other types of expenses associated with delivery of assets to the point of sale do not belong to such expenses (p. 23 of IFRS 41) (Fig. 2).

As shown in the research results, in the absence of active market for fair value measurement, information from other accessible sources is used: last selling transaction price of similar products; market prices of similar assets; basic branch prices for other products which can be calculation basis for fair value measurement of the given asset [11].

Scholars believe that in the absence of market prices and other cost indicators of biological asset that is in a particular state at the moment, current value of net cash flow that the asset is expected to generate is employed [12]. In certain cases it can not be determined, particularly: at the point of initial costing characterizing the process of unfinished production (sowing and maintenance of autumn sown cereal in autumn period), etc. Fair value of gathered agricultural products is reported in the course of income and financial results determination over a period when such products were obtained. This procedure fully conforms to product recovery by means of its separation from biological asset or while producing grain or oil bearing crops with a short biotransformation cycle (within several months of a calendar year).

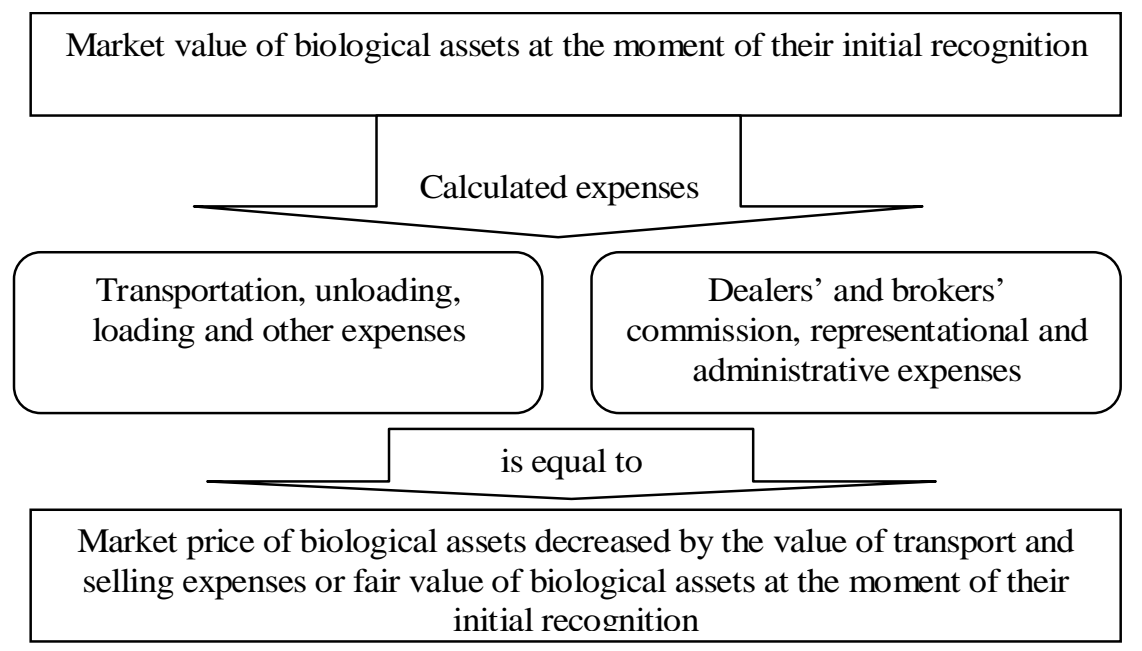

Fig. 2. Formation of fair value of biological assets at the moment of their initial recognition 
We consider that if fair value can not be determined with a sufficient degree of reliability, biological assets are measured at net cost exclusive of depreciation and impairment loss. As soon as biological assets are measured at their fair value, accrual of depreciation ceases.

However, in practical terms, there is no market for certain types of biological assets, and the nature of possible consumption and usage of such assets differs. As a result, certain difficulties emerged in the course of recognition of such biological assets at fair value.

Besides, such biological assets as fruit bearing perennial plants after achieving their fruiting stage no longer perform notable biological transformation.

Scholars claim that in relation to such biological assets valuation according to fair value is not completely correct because the nature of their usage in production process is similar to production equipment [13].

In all cases, according to IFRS 41, a change in fair value of biological asset should be considered while determining the financial results over a period when this change takes place, less the expected selling expenses. Thus, an economic entity should follow the specified procedure till the moment of its disposal.

It is necessary to point out that increase or decrease in their measurement value is recorded only if there is a change in fair value of biological assets.

The research has shown the lack of unified principles and rules for accounting of biological assets at fair value. Basically, researchers refer to the regulations of IFRS 41 "Agriculture" [13]. Particular nature of accounting system legacy and management system restrains transition to international financial reporting standards. Hence, there is a need to formulate adaptation measures for the requirements of IFRS 41 "Agriculture" ultimately on the principles of fair value measurement of biological assets [14].

In the course of investigation the following principles have been specified: 1) availability of active market in compliance with the following demands: homogeneity of transaction objects on the market, accessibility of information on prices ensuring formation of market model of perfectly competitive agricultural products; 2) objectivity and reliability of prices stipulating absence of monopolistic market segments and elimination of a large amount of intermediaries on the way from producer to the market; 3) accessibility of information on prices, which calls for the creation of data system in Ukraine that will provide authentic and available information on prices from a perspective of geographically restricted areas of active market; 4) availability of reliable reference information and economic planning information that takes into account peculiarities and techniques of farm production giving the opportunity for comparison of biological assets and outcomes of their biotransformation; 5) simplicity of algorithm and procedures of fair value measurement that supplies practical work of accountants with the simplest algorithms and methodological approaches using reliable and available information; 6) high professional level of agricultural enterprise accountants related to the introduction of new category of biological assets presupposes relevant organization of their synthetical and analytical accounting on separate inventory records that disclose relevant information on existence, flow and biotransformation of biological assets according to certain types; 7) selecting accounting policy for accounting of biological assets and outcomes of their biotransformation at fair value depending on current tasks of economic entity regarding one of three variants of information use: a) to prepare only profit and loss statement; b) to prepare accounting balance sheet as well as profit and loss statement; c) to manage enterprise biological resources. In accordance with the selected variant of accounting policy, enterprise should form relevant composition of annual, interim, and current accounting information. 8) securing unbiased measurement of economic performance of agrarian business parties that requires relevant organization of synthetical and analytical cost accounting as well as yielding capacity accounting, formation of financial results of agricultural activities.

In the course of investigation it has been established that the process of accounting and valuation of biological assets at fair price involves the following stages:

1. Determination of biological assets as an object of accounting according to their classification. The aim of this stage is to single out biological assets and business transactions that have organizational and economic independence 
and are subject to money valuation at certain points of their life cycle: formation, usage, sale and liquidation that facilitates determination of real money equivalent of fair value of biological assets results over a definite period and till certain accounting date.

2. Specification of biological assets according to culture, breed and other distinguishing features. Diversity of conditions and output of agricultural products associated with peculiarities and specific issues of the sector require separating biological assets and outcomes of their biotransformation into separate groups of biological assets and results of their biotransformation taking into consideration both natural and biological peculiarities and economic utility.

3. Investigation of active market; collection of information about prices as well as technical and economic information. It may be conceived that active market for marketable agricultural products has been formed. Several market outlets should be examined here, and a focus on existing sales markets should be made because prices vary widely depending on the country, sales region, processors, etc. For non-market types of production we should use technical and economic features that influence production quality or the content of separate elements with price/money value on the market.

4. Selection of valuation technique for biological assets. This stage is the most important. Prices and financial results of economic activity of the agrarian market entity will basically depend on valuation technique.

5. Fair value measurement. In accordance with IFRS 41 "Agriculture", costs associated with transportation, storage and other selling procedures should be taken into account in the course of fair value measurement.

6. Fair value measurement of biological assets in accordance with the approved procedure. At this stage fair value of biological assets is determined for accounting reporting purposes with a view to make managerial decisions regarding enhancement of agricultural production efficiency.

7. Disclosure of biological assets in the bookkeeping records at fair value makes it possible to obtain the most reliable and exhaustive information on activity of agricultural organizations. We believe that application of suggested methodological approaches will ensure determination of real measurement of biological assets, especially in plant growing industry.

\section{Conclusion}

Thus, under current conditions, application of IFRS, especially IFRS 41 "Agriculture", is one of key elements providing opportunities for successful and long-term performance of national agricultural enterprises with foreign contracting parties

IFRS makes a synthesis of agriculture peculiarities in the unique characteristics of agricultural activity as management of biotransformation of biological assets.

The best conditions for fair value measurement are created by the existence of active market where: regular transactions with homogeneous biological assets are carried out; seller and buyer ready to make a transaction can be found at any time; all interested parties have access to pricing information. Lack of active market complicates fair value measurement, and this is the reason why certain alternative procedures for fair value measurement may be applied (in particular, the following value alternatives may be used alongside with market value as fair value: intracompany inflation-adjusted transfer price; entity profitability; replacement cost; equilibrium price; cost of acquisition; selling cost; actual or standard cost taking into account inflation rate; discounted value, and other).

Application of fair value necessitates relevant transformations of such notions as "incomings", "expenses" and "financial results" within which it is necessary to single out earning capacity, expenses, profit and loss updated by means of using the specified valuation.

We are of the opinion that in the course of biological assets measurement it is always assumed that fair value of biological asset can be reliably measured. In order to simplify the process of fair value measurement of biological assets and agricultural products, it is worth grouping them according to age, quality and other key features.

We consider that simultaneous application of several indicators for fair value measurement may be a cause of different values of biological asset or agricultural production fair value. Agrarian business entity is obliged to examine reasons for inconsistent calculations and choose the most reliable fair value measurement.

Fair value should reflect changeability of money flows that are taken into account during price negotiation by independent, aware and interested in such transaction buyers and sellers. 
Lack of unified approach is caused by the fact that the majority of assets have no market value and their fair value, calculated by experts, is relative and valid only as of the measurement date. But, nevertheless, fair value is necessary for prospective investors and irreplaceable for financial assets.

Therefore, methods of measuring biological assets and agricultural products at fair value of biological assets need to be improved, and adjustments should be introduced into measurement models, ensuring equivalence of exchange between independent parties on active market.

Measurement of biological assets and agricultural production at fair value makes it possible to measure outcomes of agricultural activity of economic entities in an unbiased manner. This increases their opportunities concerning investment generation and competitive growth on agrarian markets.

\section{References}

1. MSFO (IAS) 41 "Selskoe khoziaistvo" [Эlektronnbii resurs] // Эlektronnble dannble. - URL: http://base.garant.ru/70108111/ [IAS 41 "Agriculture"] [Electronic resource] // Electronic data. URL: http://base.garant.ru/70108111/ (reference date 15.03.2017).

2. Mizhnarodnyi standart bukhhalterskoho obliku 41 "Biolohichni aktyvy" [Elektronnyi resurs]. - Rezhym dostupu: http://www.minfin.gov.ual file/link/320311/ file/IAS \%2041.pdfInternational

[Accounting Standard 41 "Biological Assets"] [Electronic Resource]. - Mode of access: http://www.minfin.gov.ual file / link / 320311 / file / IAS \% 2041.pdf

3. Kokorev N. Otsenka byolohycheskykh aktyvov [Evaluation of biological assets / NA Kokorev // Accounting in agriculture. - 2008. - No. 8. - P. 71.

4. International Financial Reporting Standard 2 "Sharebased Payment" [Electronic resource]. Mode of access to the resource: http://eifrs.ifrs. org/eifrs/bnstandards/en/2015/ifrs02.pdf.

5. Metodychni rekomendatsii z bukhhalterskoho obliku biolohichnykh aktyviv i silskohospodarskoi produktsii za rynkovoiu (spravedlyvoiu) vartistiu // Oblik $i$ audyt. - № 1. - 2008. - S. 5-22. [Methodological recommendations for the accounting of biological assets and agricultural products at market (fair) value // Accounting and audit. - No. 1. - 2008. - P. 5-22.

6. Mossakovskyi V. B. Stan ta perspektyvy rozvytku bukhhalterskoho obliku v Ukraini: [monohrafiia] / V. B. Mossakovskyi. - K. : Interpres LTD, 2009. 326 s. [Mossakovsky V. B. Status and prospects of accounting development in Ukraine: [monograph] / VB Mossakovsky - K.: Interpress LTD, 2009. $326 \mathrm{p}$.
7. Diakiv V. V. Upravlinskyi oblik v Ukraini - realii sohodennia / V. V. Diakiv // Ekonomika APK. 2010. - №8. - S. 76-80. Dyakov V. V. Management Accounting in Ukraine - Realities of Today / V. V. Diakov // Economy of agroindustrial complex. - 2010. - No. 8. - P. 76-80.

8. Brazilii N. M. Kontseptualni pidkhody do vartisnoho vymiriuvannia $v$ systemi bukhhalterskoho obliku / N. M. Brazilii // Visnyk universytetu bankivskoi spravy Natsionalnoho banku Ukrainy. - 2013. - № 3 (18). - S. 235-238. [Brasilii N. M. Conceptual approaches to cost measurement in the accounting system / N.M. Brasil // Bulletin of the University of Banking of the National Bank of Ukraine. - 2013. No. 3 (18). - P. 235-238.

9. MSFO (IAS) 16 “Osnovnble sredstva” [Эlektronnbli resurs] - Rezhym dostupa: http://www.ippnou.ru/ article.php? idarticle $=002712$. - Data dostupa: 29.04.2015. [IAS 16 "Fixed Assets" [Electronic Resource] - Access Mode: http://www.ippnou. ru/article.php?idarticle $=002712$. - Date of Access: Apr 29, 2014

10. MSFZ (IFRS) 13 "Otsinka spravedlyvoi vartosti" [Elektronyi resurs]. - Rezhym dostupu: http://www.minfin.gov.ua/control/publish/article/mai $n$ ?art_id=92410\&cat_id=92408. [IFRS 13 "Fair Valuation” [Electronic Resource]. - Access mode: http://www.minfin.gov.ua/control/publish/article/mai $n ?$ art_id $=92410 \&$ cat_id $=92408$.

11. Hrynchyshyn Ya. Perevahy i problemy zastosuvannia spravedlyvoi vartosti dlia otsinky biolohichnykh aktyviv// Visnyk Lvivskoho NAU: ekonomika APK.№19 (1).-2012.-S.381-385 [Grinchyshyn Ya. Benefits and problems of applying fair value for the estimation of biological assets // Visnyk of Lvivskii NAU: Economy of agroindustrial complex. - № 19 (1). - 2012. - S. 381-385

12. Koriahin M. V. Otsiniuvannia vartosti pidpryiemstva $v$ systemi bukhhalterskoho obliku : monohrafiia / M. V. Koriahin. - Lviv : TOV "NVP "Interservis". 2012. - 262 s. [ Koryagin MV Estimation of the value of the enterprise in the accounting system: monograph / M. V. Korjagin - Lviv: LLC "NVP" Interservice “. - 2012. - 262 p.

13. Piatov M. L. Pryznanye byoaktyvov $v$ otchetnosty selskokhoziaistvennblkh orhanyzatsyi / M. L. Piatov // Bukhuchet v selskom khoziaistve. - 2009. - № 9. S. 10. [Pyatov ML Recognition of bioactive substances in the reporting of agricultural organizations / M. L. Pyatov // Accounting in agriculture. - 2009. No. 9. - P. 10.

14. Kuzmovych P. Poniattia biolohichnykh aktyviv ta yikh klasyfikatsiia: oblik $i$ finansy APK // P. M. Kuzmovych. - 2010. - № 4. - S. 32-37. [Kuzmovych P.M. The notion of biological assets and their classification: Accounting and Finance APK // P. M. Kuzmovich - 2010. - No. 4. - P. 32-37. 